\title{
The Impact of Social CRM Capabilities and Customer Engagement on the Firm Performance: Mediating Role of Social Media Usage
}

\author{
Muhammad Azhar Bhatti ${ }^{1}$, Muhammad Farhan ${ }^{2}$, Munawar Javed Ahmad ${ }^{3}$, Muhammad \\ Naeem Sharif \\ ${ }^{1,}$ Department of Economics, The Islamia University of Bahawalpur, Pakistan. \\ ${ }^{2}$ Riphah International University, Islamabad, Pakistan. \\ ${ }^{3}$ Assistant Professor, Iqra University, Karachi, Pakistan. \\ ${ }^{4}$ National College for Business Administration and Economics, Lahore. Bahawalpur Campus. \\ Email: azhar.bhatti219@gmail.com
}

\begin{abstract}
This research aims to analyze the impact of social customer relationship management (CRM) capabilities and customer engagement on the firm performance in the textile industry of Pakistan. Another purpose of the article is to examine the mediating role of social media usage on the nexus of social CRM capabilities, customer relationship management and firm performance. The customer relation officers of textile industry situated in the Punjab province of Pakistan are the respondents and data were gather by using questionnaires and PLS-SEM was employed for hypotheses testing. The findings revealed that social CRM capabilities and customer engagement have positive nexus with the firm performance while social media usage positively mediates the relationship among the social CRM capabilities, customer relationship management and firm performance. These findings provide the guidance to the regulations making authorities that they should enhance their emphasis on the CRM capabilities, employee engagement and social media usage that enhance the firm performance.
\end{abstract}

Keywords: Social CRM Capabilities, Firm Performance, Customer Relationship Management, Social Media Usage

\section{Introduction}

The usage of networking on social media has rapidly expanded in the previous decade and the interest regarding the marketing on social media between the scholars of marketing and institutions has grown rapidly globally (Kamboj, Yadav, Rahman, \& Goyal, 2016). The managers feel more active and comfort to include the social media as the part of marketing communication thus their attentions regarding the performance of social media increase naturally. Most of the studies identified the benefits of the activities regarding marketing 
through social media. They defined the "social media" as the combination of technological innovations of both software and hardware that facilitates the users in terms of interoperability, interaction, and content creation (Trainor, Andzulis, Rapp, \& Agnihotri, 2014). The social media provides the platform to the customers that they interact as well as influence the on brand communities. It also provides extensive customer engagement as well as the comprehensive response rate than the traditional ways of marketing that only focuses the firm and customer relations (Foltean, Trif, \& Tuleu, 2019). The role of passive consumers are transferring from the active participants in sharing and creating of information by using the applications of social media. Nearly 35 percent of social media users are participating in the commenting on website, content writing and sharing. The applications of social media that enhance the ability of the customers in the interaction with the business firms and also empowered the users in terms of taking the active part in building their experiences. Currently, the managers of the firms are integrated with the applications of social media that are existing CRM system to adopt the new capabilities that enhance the customer satisfaction and experience (Rodriguez, Ajjan, \& Peterson, 2016).

Thus, the merger of social media and CRM system has enhanced the collaboration, interaction and approach regarding the network-focused to manage the customer relationships. Recently, the social CRM describes the new way regarding the development and management of customer relationships (Guesalaga, 2016). Marketing academics defined the social CRM as "the integration of customer-facing activities, including processes, systems, and technologies, with emergent social media applications to engage customers in collaborative conversations and enhance customer relationships" (Trainor, Rapp, Beitelspacher, \& Schillewaert, 2011). The organizations have made significant investments on the social CRM in the previous years. The present study focuses on the applications of social media and the effectiveness of social system of CRM remains unexplored (Hidayanti, Herman, \& Farida, 2018). Numerous previous researchers have exposed that the technologies of CRM are not much value added lonely but when it combined to other sources of the firm, it becomes more active (Agnihotri, Kothandaraman, Kashyap, \& Singh, 2012). However, scant studies are available that investigates the interaction of the technologies of social media with CRM systems and also attach these technologies with firm value. Resultantly, the aim of this article is to analyze that how the usage of social media help the organizations to formed the CRM capabilities and enhance the business performance. Thus, the present study developed the theoretical framework 
by using the "resource-based view" and "dynamic capabilities" theories. This study provide the insight to the managerial authorities regarding the efficacy of technology about social media.

The remaining sections are the literature regarding the variable and their relationships that followed by the research methodology. Next section regarding the finding and interpretations that is followed by the discussions and conclusion section along with the future directions and limitations.

\section{Literature Review}

In the case of traditional CRM, the firms have sufficient information regarding the customers and by using this information, they manage the relationship with customers. It is defined as the proactive, systematic management regarding the relationships from the start and to the end association with customers (Choudhury \& Harrigan, 2014). However, the social CRM capabilities are defined as the unique and meaningful combination of technologies and CRM systems that improve the retention, loyalty and customer satisfaction of the organization. In addition, the present study takes into consideration the definition of social CRM capabilities is "a firm's competency in generating, integrating, and responding to information obtained from customer interactions that are facilitated by social media technologies" (Reimann, Schilke, \& Thomas, 2010).

\section{Conceptual Framework}

\section{A. Social CRM Capabilities and Firm Performance}

According the past literature the firm performance of the organization depends upon the social CRM capabilities. In addition, the capabilities of social CRM are the major factor that enhance the performance of the institution (Ernst, Hoyer, Krafft, \& Krieger, 2011). Moreover, positives nexus has exposed by the previous studies among the capabilities of social CRM and performance of the institutions. Furthermore, as for as the capabilities of social CRM increases the firm performance also increases and vice versa (Agnihotri, Trainor, Itani, \& Rodriguez, 2017). Additionally, firm performance effected by the social CRM capabilities that is found by the latest literature. Similarly, the capabilities of social CRM increase the satisfaction and loyalty level of the customer that is the reason of high firm performance in the presence of social CRM. Likewise, the effective relationship with customer enhance by the effective capabilities of social CRM and that is necessary for the high firm performance in the institution (Chen \& Tsou, 2012). Thus, based on all literature, it is uncovered that the effective capabilities of CRM increase the customer satisfaction and loyalty that enhance the firm performance and the present study also developed the following hypothesis: 
H1: Social CRM capabilities increase the performance of the textile industry in Pakistan.

\section{B. Customer Engagement and Firm Performance}

The engagement of the customer into the product and services of the institution increases its performance. Similarly, the engagement of the customers shows the satisfaction and loyalty level of the customer that enhance the firm performance in the presence of social CRM (Benitez, Castillo, Llorens, \& Braojos, 2018). Firm performance of the organization depends upon the customer's engagement. Moreover, positives nexus has exposed by the past literature among the customer engagement and performance of the institutions. In addition, customer engagement is the major factor that enhances the performance of the institution (Garrido-Moreno, Lockett, \& Garcia-Morales, 2015). Likewise, the effective relationship with customer enhance customer's engagement with the business and that is necessary for the high firm performance in the institution. Furthermore, as for customer engagement increases, the firm performance also increases and vice versa. Additionally, firm performance effected by the customer engagement that is found by the past literature (Hartono \& Sheng, 2016). Thus, based on all literature, it is uncovered that customer engagement increase customer satisfaction and loyalty that enhance the firm performance and the present study also developed the following hypothesis:

H2: Customer engagement increases the performance of the textile industry in Pakistan.

\section{Mediating Role of Social Media Usage}

The usage of social media enhance the link and attraction among the customer that enhance the customer's satisfaction, loyalty and engagement with the institution that enhance the organizational performance (Wang \& Kim, 2017). In addition, the usage of social media enhance the effects of CRM on the relationships of customer and institutions that also increase the firm performance. Moreover, positive nexus among the usage of social media and customer relationship with customer and that is the vital factor of high firm performance. The usage of social media provided the easy and most convenient assess of the institution at their home place that increase the interaction of the customers with the firm and more the engagement and the firm performance (Hollebeek, 2019). Similarly, it is the outcome of the capabilities of CRM that the people use the social media and interact with institutions and that ultimately improve the firm performance. The use of social media is the best way to engage the customers towards the institution that enhance the ability of the firm to perform more (Jermsittiparsert, Sutduean, $\&$ Sriyakul, 2018). Thus, the use of social media is necessary to enhance the capabilities off 
CRM and customer engagement and these two factors are the major contributor that enhance the firm performance and the current study developed the hypothesis as under:

H3: Social media usage positively mediates the nexus among the social CRM capabilities and the performance of textile industry in Pakistan.

H4: Social media usage positively mediates the nexus among the customer's engagement and the performance of the textile industry in Pakistan.

\section{Research Methods}

The purpose of the literature is to analyze the impact of social CRM capabilities and customer engagement on the firm performance in the textile industry of Pakistan. Another purpose of the article is to examine the mediating role of social media usage on the nexus of social CRM capabilities, customer relationship management, and firm performance. The customer relation officers of the textile industry situated in the Punjab province of Pakistan are the respondents and data were gathered by using questionnaires and PLS-SEM was employed for hypotheses testing. Approximately 800 questionnaires were sent to them by mail and after fifteen days, only 570 valid responses were returned and used for analysis that is representing around 71.28 percent rate of response.

\section{A. Measures}

The predicting variables such as firm performance (FP) is measured by eight items while predators such as social CRM capabilities (SCRMC) and customer engagement (CE) are measured by fourteen and ten items respectively. Additionally, the mediator variable, for instance, social media usage (SMU), is measured by six items.

\section{B. Research Framework}

\section{Figure 1: Theoretical Framework}

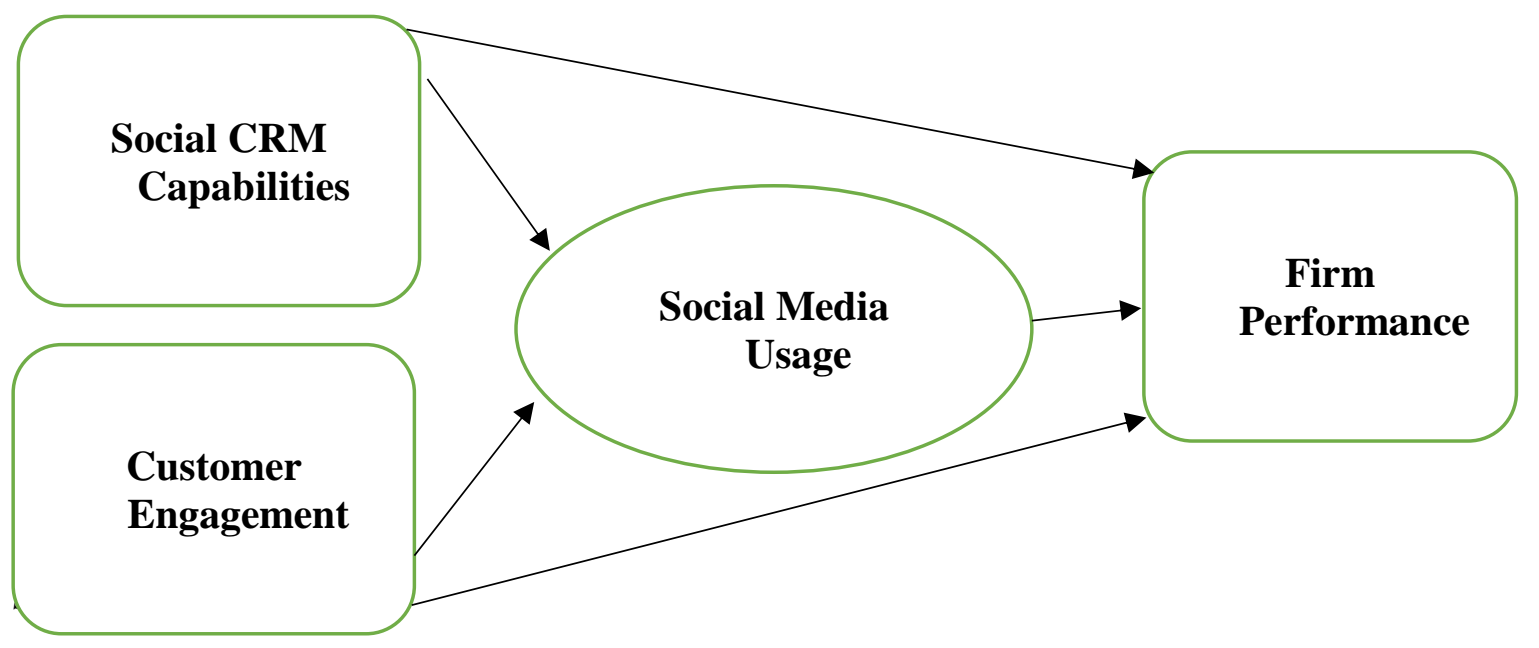




\section{Findings}

The findings consist of the validity of the constructs and testing of hypotheses by using the PLS-SEM. The validity includes the convergent as well as discriminant validity. The convergent validity shows the correlation among the items and statistics show that items are highly correlated because the values of composite reliability (CR) and Alpha are more than 0.70 while AVE and loadings are more than 0.50. Table 1 and Figure 2 show the convergent validity given below:

Table 1: Convergent Validity

\begin{tabular}{|c|c|c|c|c|c|}
\hline Constructs & Items & Loadings & Alpha & CR & AVE \\
\hline \multirow[t]{8}{*}{ Customer Engagement } & CE1 & 0.883 & 0.917 & 0.933 & 0.637 \\
\hline & CE10 & 0.718 & & & \\
\hline & CE2 & 0.865 & & & \\
\hline & CE3 & 0.731 & & & \\
\hline & CE4 & 0.649 & & & \\
\hline & CE6 & 0.811 & & & \\
\hline & CE7 & 0.780 & & & \\
\hline & CE9 & 0.910 & & & \\
\hline \multirow[t]{3}{*}{ Firm Performance } & FP1 & 0.707 & 0.849 & 0.884 & 0.524 \\
\hline & FP2 & 0.826 & & & \\
\hline & FP3 & 0.636 & & & \\
\hline \multirow[t]{5}{*}{ Constructs } & Items & Loadings & Alpha & $\mathbf{C R}$ & AVE \\
\hline & FP4 & 0.636 & & & \\
\hline & FP6 & 0.670 & & & \\
\hline & FP7 & 0.781 & & & \\
\hline & FP8 & 0.786 & & & \\
\hline \multirow[t]{10}{*}{ Social CRM Capabilities } & SCRMC1 & 0.792 & 0.928 & 0.938 & 0.583 \\
\hline & SCRMC10 & 0.768 & & & \\
\hline & SCRMC12 & 0.760 & & & \\
\hline & SCRMC14 & 0.789 & & & \\
\hline & SCRMC2 & 0.861 & & & \\
\hline & SCRMC3 & 0.556 & & & \\
\hline & SCRMC4 & 0.782 & & & \\
\hline & SCRMC5 & 0.697 & & & \\
\hline & SCRMC6 & 0.726 & & & \\
\hline & SCRMC7 & 0.826 & & & \\
\hline
\end{tabular}


Pakistan Journal of Humanities and Social Sciences, 7(3), 2019

\begin{tabular}{|l|l|l|l|l|l|}
\hline & SCRMC8 & 0.798 & & & \\
\hline Social Media Usage & SMU1 & 0.790 & 0.857 & 0.894 & 0.585 \\
\hline & SMU2 & 0.710 & & & \\
\hline & SMU3 & 0.820 & & & \\
\hline & SMU4 & 0.841 & & & \\
\hline & SMU5 & 0.699 & & & \\
\hline & SMU6 & 0.716 & & & \\
\hline
\end{tabular}

The discriminant validity shows the correlation among the constructs and statistics show that constructs are not highly correlated because the first value of the construct is more than the rest. Table 2 shows the discriminant validity by using Fornell Larcker criteria given below:

Table 2: Fornell Larcker

\begin{tabular}{|l|c|c|c|c|}
\hline & CE & FP & SCRMC & SMU \\
\hline CE & 0.798 & & & \\
\hline FP & 0.568 & 0.724 & & \\
\hline SCRMC & 0.398 & 0.534 & 0.764 & \\
\hline SMU & 0.684 & 0.710 & 0.494 & 0.765 \\
\hline
\end{tabular}

The discriminant validity shows the correlation among the constructs and statistics show that constructs are not highly correlated because the values of the constructs more than the values of the rest of the constructs. Table 3 shows the discriminant validity by using crossloadings criteria given below:

Table 3: Cross Loadings

\begin{tabular}{|l|c|c|c|c|}
\hline & CE & FP & SCRMC & SMU \\
\hline CE1 & $\mathbf{0 . 8 8 3}$ & 0.438 & 0.286 & 0.515 \\
\hline CE10 & $\mathbf{0 . 7 1 8}$ & 0.394 & 0.378 & 0.434 \\
\hline CE2 & $\mathbf{0 . 8 6 5}$ & 0.391 & 0.284 & 0.507 \\
\hline CE3 & $\mathbf{0 . 7 3 1}$ & 0.509 & 0.287 & 0.616 \\
\hline CE4 & $\mathbf{0 . 6 4 9}$ & 0.428 & 0.316 & 0.533 \\
\hline CE6 & $\mathbf{0 . 8 1 1}$ & 0.334 & 0.224 & 0.409 \\
\hline CE7 & $\mathbf{0 . 7 8 0}$ & 0.559 & 0.380 & 0.677 \\
\hline CE9 & $\mathbf{0 . 9 1 0}$ & 0.470 & 0.339 & 0.544 \\
\hline FP1 & 0.452 & $\mathbf{0 . 7 0 7}$ & 0.292 & 0.391 \\
\hline FP2 & 0.326 & $\mathbf{0 . 8 2 6}$ & 0.386 & 0.478 \\
\hline FP3 & 0.367 & $\mathbf{0 . 6 3 6}$ & 0.295 & 0.329 \\
\hline FP4 & 0.366 & $\mathbf{0 . 6 3 6}$ & 0.405 & 0.429 \\
\hline FP6 & 0.466 & $\mathbf{0 . 6 7 0}$ & 0.439 & 0.607 \\
\hline
\end{tabular}




\begin{tabular}{|l|l|l|l|l|}
\hline FP7 & 0.452 & $\mathbf{0 . 7 8 1}$ & 0.467 & 0.671 \\
\hline FP8 & 0.423 & $\mathbf{0 . 7 8 6}$ & 0.358 & 0.556 \\
\hline SCRMC1 & 0.190 & 0.351 & $\mathbf{0 . 7 9 2}$ & 0.232 \\
\hline SCRMC10 & 0.180 & 0.301 & $\mathbf{0 . 7 6 8}$ & 0.238 \\
\hline SCRMC12 & 0.250 & 0.351 & $\mathbf{0 . 7 6 0}$ & 0.302 \\
\hline SCRMC14 & 0.354 & 0.406 & $\mathbf{0 . 7 8 9}$ & 0.382 \\
\hline SCRMC2 & 0.428 & 0.502 & $\mathbf{0 . 8 6 1}$ & 0.479 \\
\hline SCRMC3 & 0.245 & 0.246 & $\mathbf{0 . 5 5 6}$ & 0.289 \\
\hline SCRMC4 & 0.365 & 0.477 & $\mathbf{0 . 7 8 2}$ & 0.468 \\
\hline SCRMC5 & 0.389 & 0.438 & $\mathbf{0 . 6 9 7}$ & 0.466 \\
\hline SCRMC6 & 0.298 & 0.438 & $\mathbf{0 . 7 2 6}$ & 0.458 \\
\hline SCRMC7 & 0.263 & 0.423 & $\mathbf{0 . 8 2 6}$ & 0.352 \\
\hline SCRMC8 & 0.233 & 0.408 & $\mathbf{0 . 7 9 8}$ & 0.300 \\
\hline SMU1 & 0.647 & 0.495 & 0.355 & $\mathbf{0 . 7 9 0}$ \\
\hline SMU2 & 0.416 & 0.632 & 0.436 & $\mathbf{0 . 7 1 0}$ \\
\hline SMU3 & 0.622 & 0.507 & 0.391 & $\mathbf{0 . 8 2 0}$ \\
\hline SMU4 & 0.649 & 0.531 & 0.358 & $\mathbf{0 . 8 4 1}$ \\
\hline SMU5 & 0.343 & 0.514 & 0.351 & $\mathbf{0 . 6 9 9}$ \\
\hline SMU6 & 0.415 & 0.585 & 0.376 & $\mathbf{0 . 7 1 6}$ \\
\hline
\end{tabular}

The new criteria to check the discriminant validity is the Heterotrait and Monotrait (HTMT) ratio and according to this ratio discriminant validity is valid because values are higher than 0.90 . Table 4 show the discriminant validity by using HTMT ratio given below:

Table 4: HTMT Ratio

\begin{tabular}{|l|l|l|l|l|}
\hline \multicolumn{1}{|c|}{} & CE & FP & SCRMC & SMU \\
\hline CE & & & & \\
\hline FP & 0.623 & & & \\
\hline SCRMC & 0.408 & 0.569 & & \\
\hline SMU & 0.742 & 0.803 & 0.532 & \\
\hline
\end{tabular}




\section{Figure 2: Measurement Model Assessment}

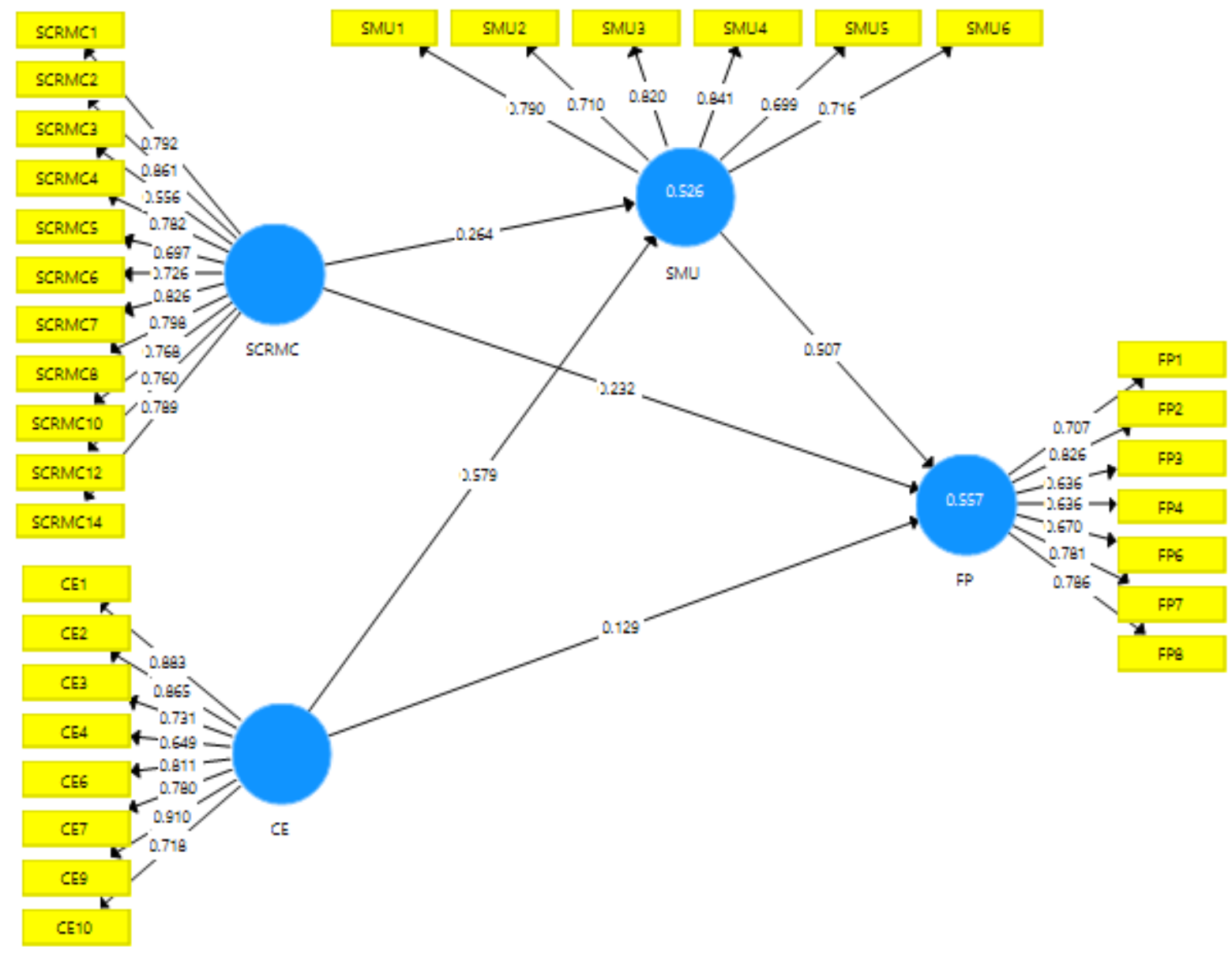

Source: The authors

The path analysis shows the testing of hypotheses, and the statistics show that positive nexus among the social CRM capabilities, customer engagement and firm performance because positive signs shown by the beta values. In addition, the statistics also show that significant nexus among the social CRM capabilities, customer engagement and firm performance because t-statistics and probabilities values are meet the standard criteria and accepted the H1 and H2. These results are matched with outcomes of (Coltman, Devinney, \& Midgley, 2011) who also found positive and significant links with them. Moreover, usage of social media also positively mediated the link among the social CRM capabilities, customer engagement and firm performance and accepted the $\mathrm{H} 3$ and $\mathrm{H} 4$. Table 5 and Figure 3 given below show the path analysis. 
Table 5: Path Analysis

\begin{tabular}{|l|l|l|c|r|l|l|}
\hline & Beta & S.D. & t-values & p-value & L.L. & U.L. \\
\hline CE -> FP & 0.129 & 0.056 & 2.315 & 0.011 & 0.036 & 0.222 \\
\hline CE -> SMU & 0.579 & 0.048 & 12.027 & 0.000 & 0.501 & 0.656 \\
\hline SCRMC -> FP & 0.232 & 0.050 & 4.607 & 0.000 & 0.148 & 0.315 \\
\hline SCRMC -> SMU & 0.264 & 0.054 & 4.919 & 0.000 & 0.172 & 0.352 \\
\hline SMU -> FP & 0.507 & 0.063 & 8.096 & 0.000 & 0.403 & 0.599 \\
\hline CE -> SMU -> FP & 0.294 & 0.044 & 6.678 & 0.000 & 0.224 & 0.370 \\
\hline SCRMC -> SMU -> FP & 0.134 & 0.034 & 3.995 & 0.000 & 0.078 & 0.189 \\
\hline
\end{tabular}

\section{Figure 3: Structural Model Assessment}

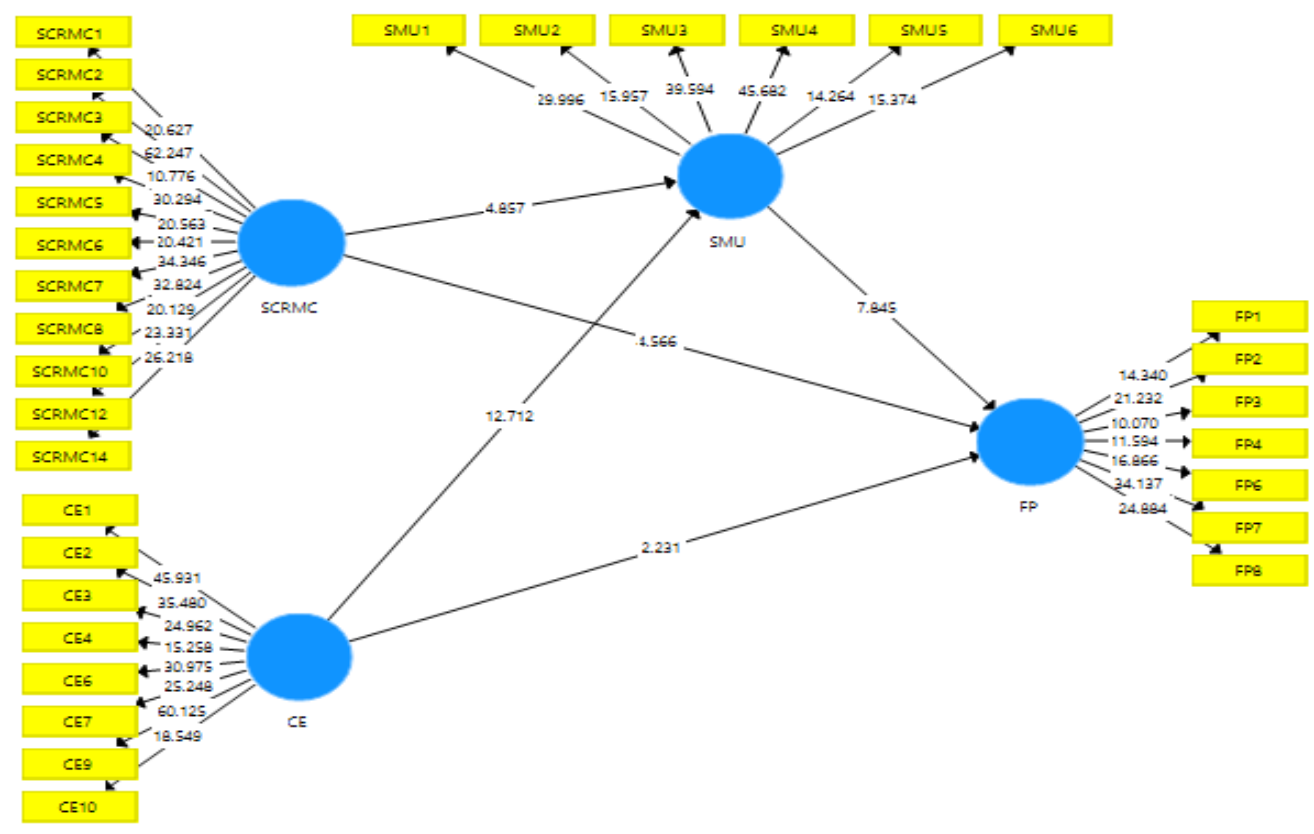

Source: The authors

\section{Discussions and Conclusion}

The aim of the article is to analyze the impact of social CRM capabilities and customer engagement on the firm performance in the textile industry of Pakistan. Another purpose of the article is to examine the mediating role of social media usage on the nexus of social CRM capabilities, customer relationship management and firm performance. The findings revealed that social CRM capabilities and customer engagement have positive nexus with the firm performance. The effective capabilities of social CRM enhance the customer satisfaction and loyalty that increase the output and sale of the company that leads the organization towards the high performance. Social media usage positively mediates the relationship among the social 
Pakistan Journal of Humanities and Social Sciences, 7(3), 2019

CRM capabilities, customer relationship management and firm performance. When the people use the social media they can interact with the organization more easily at their home place that improves the employee engagement and also CRM capabilities that ultimately improve the firm performance. These findings provide the guidance to the regulations making authorities that they should enhance their emphasis on the CRM capabilities, employee engagement and social media usage that enhance the firm performance.

Hence, the conclusion drawn by the article is that effective capabilities of social CRM enhance customer satisfaction and loyalty that increase the output and sale of the company that leads the organization towards the high performance. When the people use the social media they can interact with the organization more quickly at their home place that improves the employee engagement and also CRM capabilities that ultimately improve the firm performance. Finally, the current literature has some future directions and limitations for upcoming studies. For instance, the outcomes of present study generalized only in the Pakistan and in textile sector and prospective studies must include other industries and countries in their investigations. This study take only two predictors for the firm performance and upcoming studies should include more and other predictors in their analysis.

\section{References}

Agnihotri, R., Kothandaraman, P., Kashyap, R., \& Singh, R. (2012). Bringing "social" into sales: The impact of salespeople's social media use on service behaviors and value creation. Journal of Personal Selling \& Sales Management, 32(3), 333-348.

Agnihotri, R., Trainor, K. J., Itani, O. S., \& Rodriguez, M. (2017). Examining the role of salesbased CRM technology and social media use on post-sale service behaviors in India. Journal of Business Research, 81, 144-154.

Benitez, J., Castillo, A., Llorens, J., \& Braojos, J. (2018). IT-enabled knowledge ambidexterity and innovation performance in small US firms: The moderator role of social media capability. Information \& Management, 55(1), 131-143.

Chen, J.-S., \& Tsou, H.-T. (2012). Performance effects of IT capability, service process innovation, and the mediating role of customer service. Journal of Engineering and Technology Management, 29(1), 71-94.

Choudhury, M. M., \& Harrigan, P. (2014). CRM to social CRM: the integration of new technologies into customer relationship management. Journal of Strategic Marketing, 22(2), 149-176.

Coltman, T., Devinney, T. M., \& Midgley, D. F. (2011). Customer relationship management and firm performance. Journal of Information Technology, 26(3), 205-219.

Ernst, H., Hoyer, W. D., Krafft, M., \& Krieger, K. (2011). Customer relationship management and company performance - the mediating role of new product performance. Journal of the academy of marketing science, 39(2), 290-306. 
Foltean, F. S., Trif, S. M., \& Tuleu, D. L. (2019). Customer relationship management capabilities and social media technology use: Consequences on firm performance. Journal of Business Research, 104, 563-575.

Garrido-Moreno, A., Lockett, N., \& Garcia-Morales, V. (2015). Exploring the role of knowledge management practices in fostering customer relationship management as a catalyst of marketing innovation. Baltic Journal of Management, 10(4), 393-412.

Guesalaga, R. (2016). The use of social media in sales: Individual and organizational antecedents, and the role of customer engagement in social media. Industrial Marketing Management, 54, 71-79.

Hartono, R., \& Sheng, M. L. (2016). Knowledge sharing and firm performance: the role of social networking site and innovation capability. Technology Analysis \& Strategic Management, 28(3), 335-347.

Hidayanti, I., Herman, L. E., \& Farida, N. (2018). Engaging customers through social media to improve industrial product development: the role of customer co-creation value. Journal of Relationship Marketing, 17(1), 17-28.

Hollebeek, L. D. (2019). Developing business customer engagement through social media engagement-platforms: an integrative SD logic/RBV-informed model. Industrial Marketing Management, 81, 89-98.

Jermsittiparsert, K., Sutduean, J., \& Sriyakul, T. (2018). Social Customer Relationship Management Capabilities and Customer Relationship Performance: Moderating Role of Social Media (face-book) usage among Indonesian firms. Opción, 34(86), 12571273.

Kamboj, S., Yadav, M., Rahman, Z., \& Goyal, P. (2016). Impact of social CRM capabilities on firm performance: Examining the mediating role of co-created customer experience. International Journal of Information Systems in the Service Sector (IJISSS), 8(4), 116.

Reimann, M., Schilke, O., \& Thomas, J. S. (2010). Customer relationship management and firm performance: the mediating role of business strategy. Journal of the academy of marketing science, 38(3), 326-346.

Rodriguez, M., Ajjan, H., \& Peterson, R. M. (2016). Social media in large sales forces: an empirical study of the impact of sales process capability and relationship performance. Journal of Marketing Theory and Practice, 24(3), 365-379.

Trainor, K. J., Andzulis, J. M., Rapp, A., \& Agnihotri, R. (2014). Social media technology usage and customer relationship performance: A capabilities-based examination of social CRM. Journal of Business Research, 67(6), 1201-1208.

Trainor, K. J., Rapp, A., Beitelspacher, L. S., \& Schillewaert, N. (2011). Integrating information technology and marketing: An examination of the drivers and outcomes of e-Marketing capability. Industrial Marketing Management, 40(1), 162-174.

Wang, Z., \& Kim, H. G. (2017). Can social media marketing improve customer relationship capabilities and firm performance? Dynamic capability perspective. Journal of Interactive Marketing, 39, 15-26. 